\title{
SOCIALLY RESPONSIBLE PROPERTY INVESTMENT IN CITIES - BETWEEN ECONOMIC REASONING AND SOCIAL OBLIGATIONS
}

\author{
Dominika P. Brodowicz, assist. prof., PhD \\ Innovative City Department \\ Collegium of Business Administration \\ Warsaw School of Economics \\ e-mail:dominika.brodowicz@sgh.waw.pl
}

\begin{abstract}
This article focuses on socially responsible property investment (SRPI), which is an investment estimated not only to bring financial gain but also social and environmental benefits. The theoretical part of the paper draws on existing literature on responsible investment. The empirical part discussed in this article is based on original research conducted by the author. Starting with a global and regional overview, the query was narrowed down to a national level (Poland) with a case study of the capital - Warsaw. The overarching research problem was described as follows: How are SRPI principles manifested and implemented by investors in the commercial real estate market? Additionally, investigation was supported by numerous questions regarding the interest in SRPI and an understanding of its principles and benefits among investors. Research goals were pursued based on primary and secondary data sources regarding existing and planned SRPI projects within the commercial real estate industry. Results indicate that there is a disparity between declared support for SRPI and market practice. At the conceptual level, there is an understanding of responsible investment principles and will to conduct such projects. However, commercial property practice proves a different reality with primary focus on green buildings, while the social factor is missing.
\end{abstract}

Key words: socially responsible property investment (SRPI), commercial real estate market, green building, LEED, BREEAM.

JEL Classification: $A 10, A 14$.

Citation: Brodowicz D.P., 2017, Socially Responsible Property Investment in Cities - Between Economic Reasoning and Social Obligations, Real Estate Management and Valuation, vol. 25, no. 2, pp. 33-44.

DOI: 10.1515/remav-2017-0011

\section{Introduction}

Over the past few years, issues related to SRPI and responsible property investing (RPI), which are very similar concepts and used in this article interchangeably, have appeared with increasing frequency on corporate agendas, as well as in political and academic discussions. One of the main reasons for this situation is the global financial crisis (GFC) of 2007-2008, which had a negative impact not only on the financial markets (NEUHAUSER 2015), but also on the property market. The housing market was weakened on a global scale (WANG and ZHANG 2013; KUCHARSKA-STASIAK and ŹRÓBEK 2015) and, therefore, also societies. After a wave of corporate bankruptcies caused by the housing bubble, including Bear Stearns in 2007 and Lehman Brothers in 2008 (NEUHAUSER 2015), businesses are now monitored more often, especially in the United States and Europe, where public bodies and non-governmental organizations (NGOs) have become involved in this area. The GFC proved that "the financing of real estate development activity is often higher up the risk curve for investors" (SQUIRES et al. 2016, p. 55). Therefore, as a needed outcome of the recent crisis, more attention has been 
focused on risk pricing, return requirement, and a correct debt to equity mix (ADAIR et al. 2011). This concerns both corporate and private investors.

However, GFC is not the only factor forcing a change towards SRPI in the real estate market. Sustainable development is one of them. Referring to the widely quoted "Our Common Future" report, it is a "development which meets the needs of the present without compromising the ability of future generations to meet their own needs" (World Commission on Environment and Development 1987, p. 43). The concept has gained recognition among property professionals. Yet, recognition does not mean a full understanding and support. In the real estate market, support for SRPI and sustainability is mainly manifested in the form of green building design and energy certification (SAYCE 2013). In this context, the article presents results of three research projects conducted by the author between 2007 and 2016, in which the issue of SRPI was investigated. Initially, the global and regional perspective was explored; next, the research focused on Poland and Warsaw as a case study.

\section{Literature review - socially responsible property investment}

SRPI, as a specific type of investing in the real estate market, is a relatively new but rapidly growing concept in investment. It has numerous working definitions, but, in general, is an investment in real estate which, in addition to financial gains, also takes into account social and environmental aspects (PIVO 2005). This refers both to direct and indirect investment projects (MARCINEK 2012). Responsible investing in properties is a part of a large area of socially responsible investing (SRI), which emerged in the 1960s as a reconciliation of financial objectives with the ethics and values of investors (SCHUETH 2003). SRPI is investing "that considers the social and environmental consequences of investments, both positive and negative, within the context of rigorous financial analysis" (SIF 2003). NEWELL (2009) states that SRPI goes beyond compliance with minimum legal requirements in order to address environmental, social and governance issues. In the environmental context, responsible investment decisions need to be based on a comprehensive data basis, including climate forecasts, as the locations of properties are fixed for long period of time (HIRSCH, BRAUN and BIENERT 2015). In the social context, RPI can include cooperation with local communities in the investment process and engagement of stakeholders in public consultations on planned developments (BRYX 2014). In SRPI, like in any other investment, an absolute prerequisite is the expected rate of return on investment (ROI), yet it is not the only factor. Referring to data provide by SIF in 2003, 2.16 trillion dollars were invested in responsible investments in the American economy alone, including the property market. In 2014, there were already over 6.57 trillion dollars in responsible assets (US SIF 2014). According to PIVO (2005) the viability of this approach can be demonstrated by the triple bottom line (TBL), by which investors evaluate projects in terms of their financial profitability, ecological integrity and social equity. In essence, TBL is primarily an accounting framework that incorporates three dimensions of performance: social, environmental and economic (ELKINGTON 2004). Nowadays, it has become more widely used and is often referred to as the "three Ps": people, planet and profits (SLAPER and HALL 2011).

In the real estate market, the inclusion of responsible investment principles by decision-makers representing the investment sector can be driven by numerous factors, including (UNEP FI 2016):

1) Understanding the impact of environmental and social issues, such as climate change and mass urbanization, on macro property trends that could damage or enhance the long-term performance of property assets.

2) Gaining a competitive advantage by getting ahead of more stringent regulatory environmental and social requirements to lessen the financial risk of retrofitting newly finished buildings.

3) Strengthening collaboration between the different groups of stakeholders taking part in the investment and use of property.

4) Inducing public pressure on investors to hold responsibility for their assets in terms of the environmental performance and social impact.

5) Responding to potential buyer and tenant demands for green and smart buildings that could contribute to lower environmental impact and utility bills.

The implementation of SRPI principles is important not only for the property industry, but for the built-up environment in general, especially in the light of evidence regarding the environmental impact of properties and ethical considerations (RATCLIFFE, O'BRIEN and BRODOWICZ 2009; SIEMIŃSKA 2013). Buildings have an impact on the environment and even small improvements in their energy efficiency and waste management can contribute to major reductions of the ecological footprint on a 
global scale (JUNNILA 2004; EERIAINEN and SARASOJA 2013). For instance, building operations are responsible for $42 \%$ of total energy consumption in the $\mathrm{EU}$, and for $35 \%$ of carbon dioxide emissions into the atmosphere (PIVO and MCNAMARA 2005, UNEP FI 2016). Investment in green buildings and smart solutions are, therefore, a response to rising energy costs, as well as fees for waste disposal and water consumption (BRODOWICZ, POSPIESZNY and GRZYMAŁA 2015). As in the case of SRPI, there is no universal definition of a green building, though there are a number features characterising them, including (YUDELSON 2008):

- efficient use of energy, water, and other resources (e.g. smart meters, zone air conditioning and clean, energy-powered heating/cooling systems),

- protection of users' health and wellbeing (e.g. access to daylight, superior air quality and noise control),

- reduction of waste and pollution produced onsite (e.g. reuse of grey water, green and brown roofs).

SHIERS (2000) considered green properties to be one of the most exciting financial opportunities in the United Kingdom (UK) and North American real estate markets in recent years. However, there are numerous economic doubts related to the profitability of investing in green buildings as compared to traditional structures. Data from the U.S. Green Building Council shows that, on average, green projects are more expensive than traditional ones at the construction stage. They only generate savings in the operational and maintenance stages of the building's life-cycle (BLOOMFIELD 2011). As early as 2007, ELLISON and SAYCE urged for the development of tools to assess investment worth and monitor the performance of buildings to support the shift towards sustainability agenda in the real estate market. However, such tools have not yet been developed (SAYCE 2013). Evidence regarding the benefits of responsible investment and savings in buildings performance comes from the market itself. Green buildings can save approximately $25 \%-50 \%$ in energy, $40 \%$ in water, and as much as $50 \%$ in waste, compared with conventional buildings (COLLIERS 2012). It should also be emphasized that the value of a building with a green certificate is potentially higher than that of a traditional one located in the same area and with similar cubage. Most buildings around the world, including Poland, are evaluated using one of two systems: the Building Research Establishment's Environmental Assessment Method (BREEAM) and the Leadership in Energy and Environmental Design (LEED) (BELNIAK, GEUSZAK and ZiĘBA 2013; BRODOWICZ, POSPIESZNY and GRZYMAŁA 2015).

\section{Data and methods}

The results discussed in this article are derived from three separate, yet thematically interconnected studies carried out by the author between 2007-2016. The studies included multiple layers and views from a global perspective, down to the EU, Poland and finally, Warsaw:

1) Study 1 - "Built Environment Foresight 2030: Sustainable Development Imperative project" was methodologically based on Futures Research and Foresight methodology including ten research steps, like environmental scanning and scenario development. Overall, there were three regional workshops conducted in London (November 2007), Hong-Kong (July 2008) and Chicago (June 2009). The study also included over two dozen interviews and strategic conversations, three in-depth surveys and extensive secondary research conducted between 2007 and 2010.

2) Study 2 - The data gathering process in "Responsible investing in the real estate market barriers and opportunities for investors" involved documentary research, comparative studies regarding companies and projects, both in the EU and in Poland alone, a survey questionnaire and case study analysis. The project was carried out between 2010 and 2013.

3) Study 3 - The research strategy applied to "Green strategies for cities in Poland - a comparative study of Warsaw, Krakow and Poznan" for gathering and analysing data was similar to the approach used in Study 2. In this case SRPI was only one element of the enquiry, not the main objective. The project started with extensive documentary research on green and socially responsible real estate projects completed in Warsaw since 2007. The gathered data and issues were then verified by interviews and group discussions with experts representing the public and private sector.

Multiple qualitative and quantitative methods were applied during this nearly decade-long academic investigation of SRPI. Both secondary and primary research was conducted, including 
documentary research, workshops, interviews and questionnaires. Over 100 real estate practitioners took part. Triangulation and crystallisation were adopted as strategies for achieving reliability and enabling aggregation of data from multiple market and academic sources. The first strategy, triangulation, is a process, in which various methods are simultaneously applied to clarify meaning and interpretation (DENZIN and LINCOLN et al. 2005). In the case of this investigation, this included the use of questionnaires, interviews and documentary research to enable comparison. The second strategy, crystallisation, is a process in which the researcher investigates the problem from different points of view to gather multiple perspectives (DENZIN and LINCOLN et al. 2005). In this study, it was used for obtaining accurate data verified by market experts.

\section{Empirical results}

\subsection{BEF 2030 project results}

The BEF 2030 project was focused on the challenge of incorporating sustainable development into the built-up environment. The issue of social responsibility of enterprises operating in the commercial real estate market and concomitant application of SRPI principles were one of its strands. The project was carried out between 2007 and 2010 by The Futures Academy team, including the author, and supported by King Sturge and the RICS Foundation. The study involved more than 100 professionals and academics from Europe, the US and Asia-Pacific. They represented both international corporations engaged in, amongst other matters, investment consulting and property management (JLL, CBRE), as well as smaller companies with a long tradition of social responsibility (Grosvenor), the US (DePaul University and Purdue University) and Hong Kong (Hong Kong University).

As a result, this study identified numerous reasons for the application of SRPI within the commercial real estate industry, approved by participants from all three-research regions. Among the vast number of data and opinions gathered over the course of the 3-year project, those most frequently discussed were:

- risk management tool - the application of SRPI principles was seen as a risk mitigation tool, especially in cases of labor law violation by subcontractors and environmental contamination of construction sites;

- stakeholders - the growing importance of stakeholders, such as local communities where projects are realised and urban activists, who can have a great influence on both positive and negative images of investors;

- climate change - the on-going climate change process and growing probability of natural disasters caused by extreme weather conditions, which can have a negative influence on building operations and tenant safety;

- personal values - the incoming wave of young investors from so-called Generation Y (Gen Y), also referred as Millennials, born between 1977 and 1994. This generation has a growing tolerance for diversity in both private and public areas of life and is value-oriented (MORTON 2002, p. 46). According to experts taking part in the study, these investors are more interested in investing in companies listed on responsibility indexes like FTSE4Good and Dow Jones Sustainability Index than in companies without records on responsibility;

- cost of utilities - economically SRPI was justified as a responsible solution - especially in the form of green buildings - to lower utility bills and property insurance.

Following qualitative discussion on the issue of responsibility in commercial real estate "Five Big Questions" regarding the future of the real estate industry were considered with experts participating in the study during the workshops and interviews. These were:

1) How will we think?

2) Will we behave differently?

3) What about real estate?

4) Who will be involved?

5) What lies ahead?

The first one, "How will we think?", was focused on current mistakes and recommendations for decision-makers. The second, "Will we behave differently?", regarded actual actions. The third question, "What about real estate?", was especially important at the dawn of the economic downturn and housing bubble in the US and other countries during which this study was conducted. The fourth question, "Who will be involved?", aimed to identify future leaders of 
progressive and responsible thinking. Last but not least, "What lies ahead?", was a thoughtprovoking question regarding development perspectives for the industry toward the year 2030 . Table 1 presents aggregated results connected with the concept of SRPI.

Table 1

BEF 2030 Big Questions session results referring to SRPI

\begin{tabular}{|c|c|c|}
\hline Question & $\begin{array}{l}\text { Answers referring to the } \\
\text { concept of SRPI }\end{array}$ & Foreseen influence on SRPI development \\
\hline \multirow{3}{*}{$\begin{array}{l}\text { How will we } \\
\text { think? }\end{array}$} & Responsibly & $\begin{array}{l}\text { Positive, but practically based on social values. Experts } \\
\text { were referring to the financial crisis of } 2008 \text {. }\end{array}$ \\
\hline & Strategically & $\begin{array}{l}\text { Positive, referring to the long-term consequences of } \\
\text { decisions. Experts stressed the length of the investment } \\
\text { process and life-cycle of an average building. }\end{array}$ \\
\hline & Creatively & $\begin{array}{l}\text { Both positive and negative, creative thinking could } \\
\text { favour only economic gain instead or social considerations. }\end{array}$ \\
\hline \multirow{3}{*}{$\begin{array}{l}\text { Will we } \\
\text { behave } \\
\text { differently? }\end{array}$} & With values & Positive, connected with business ethics and values. \\
\hline & With responsibility & $\begin{array}{l}\text { Positive, similar to previous one and in line with social } \\
\text { values. }\end{array}$ \\
\hline & With cross-disciplinarily & $\begin{array}{l}\text { Positive, cross-disciplinary thinking is an absolute basis } \\
\text { for connecting financial profitability with social equity } \\
\text { according to study participants. }\end{array}$ \\
\hline \multirow[t]{3}{*}{$\begin{array}{l}\text { What about } \\
\text { real estate? }\end{array}$} & $\begin{array}{l}\text { Two-tier market of } \\
\text { green and non-green } \\
\text { buildings }\end{array}$ & $\begin{array}{l}\text { Positive, it creates space for development of responsible } \\
\text { projects and allows also non-green investments, which } \\
\text { are still a majority of initiatives in the global scale. }\end{array}$ \\
\hline & Alteration of location & $\begin{array}{l}\text { Positive, it gives recognition to other features of } \\
\text { properties, including the quality of design, aesthetics, } \\
\text { influence on the built-up environment and nature. }\end{array}$ \\
\hline & $\begin{array}{l}\text { Qualitative assessment } \\
\text { of buildings }\end{array}$ & $\begin{array}{l}\text { Positive, if it will also include factors like the impact on } \\
\text { local communities, availability of public space and } \\
\text { development of mixed-use projects. }\end{array}$ \\
\hline \multirow{3}{*}{$\begin{array}{l}\text { Who will be } \\
\text { involved? }\end{array}$} & $\begin{array}{l}\text { Public-private } \\
\text { partnerships }\end{array}$ & $\begin{array}{l}\text { Positive, if it will involve public consultations and micro } \\
\text { financing enabling small investors to take part. }\end{array}$ \\
\hline & Communities & $\begin{array}{l}\text { Positive, it creates space for social inclusion in the } \\
\text { investment process exceeding mandatory public } \\
\text { consultations. }\end{array}$ \\
\hline & Regulators & $\begin{array}{l}\text { Positive, if regulators will enforce by law the inclusion } \\
\text { of SRPI principles in the commercial projects and offer } \\
\text { incentives such as tax reliefs. }\end{array}$ \\
\hline \multirow[t]{3}{*}{$\begin{array}{l}\text { What lies } \\
\text { ahead? }\end{array}$} & $\begin{array}{l}\text { Mainstreaming green } \\
\text { development }\end{array}$ & $\begin{array}{l}\text { Positive, societies can benefit from green projects } \\
\text { through lowering negative environmental impact and } \\
\text { health hazards caused by buildings operations. }\end{array}$ \\
\hline & $\begin{array}{l}\text { Profiting from a } \\
\text { responsible and } \\
\text { sustainable future }\end{array}$ & $\begin{array}{l}\text { Positive, if benefits from SRPI will be quantifiable and } \\
\text { feasible and positive examples of responsible projects } \\
\text { will be supported by organisations like the Urban Land } \\
\text { Institute (ULI). }\end{array}$ \\
\hline & $\begin{array}{l}\text { Defusing the } \\
\text { demographic time bomb }\end{array}$ & $\begin{array}{l}\text { Positive, if private investors will take demographic } \\
\text { forecasts on the size of urban population and needs of } \\
\text { an ageing population (grey future) into consideration. }\end{array}$ \\
\hline
\end{tabular}

While analysing BEF 2020 material, it should be emphasized that some of the expert opinion was merely "wishful thinking," and their reaction to the on-going financial crisis. The timeframe in which the project was carried out was marked by the negative consequences of the economic downturn. During workshops and in numerous interviews, participants often suggested the twin issues of corporate ethics and the social responsibility of decision-makers as remedies for housing bubbles and 
the financial crisis in the real estate industry towards the year 2030, though without the belief that they could heal the industry in the short term. Conclusions from this study were used as a reference for further research focused on Poland, proving that there is an understanding of SRPI and general interest in this type of investing.

\subsection{Responsible investment in the real estate market - barriers and opportunities for investors - results}

After obtaining interactive and statistical data related to responsible investment from a global perspective, the next step for the author was to focus on EU countries, and specifically Poland. Research was carried out between 2010 and 2012 with a grant from the National Science Centre. The project was titled "Responsible investing in the real estate market - barriers and opportunities for investors" and tackled numerous issues and challenges regarding SRPI; however, given the scope of this article, only economic and social issues will be discussed.

In order to determine the level of knowledge and the understanding of issues related to responsible investment amongst companies operating in the domestic commercial real estate market, the author conducted a survey entitled "RPI in Poland". The choice of investors to be contacted was made on the basis of market reports by JLL, Colliers and Knight Frank, regarding top property investments in Poland between 2007-2010. The survey was carried out near the end of 2012 and was anonymous. The questions asked offered multiple-choice answers with the option of adding own comments. Out of the 25 entities, including Uniball - Rodamco, Capital Park Group and Hochtief Development, to which the questionnaire was sent, 12 answered ( $\mathrm{N}=12$, response rate 48\%). Among the companies invited to respond were also Skanska Property and Ghelamco, whose Warsaw-based projects were investigated in this study and also in a third project discussed further in this article.

\subsubsection{Economic factors inhibiting and supporting development of SRPI}

Amongst the barriers to SRPI in Poland, respondents first cited the high initial cost of such investments $(66.7 \%)$, with the relatively low level of demand for green projects $(50 \%)$ being of secondary importance, while the lack of financial products such as green REIT (41.7\%) ranked third (refer to Figure 1). None of the respondents added comments to this question.

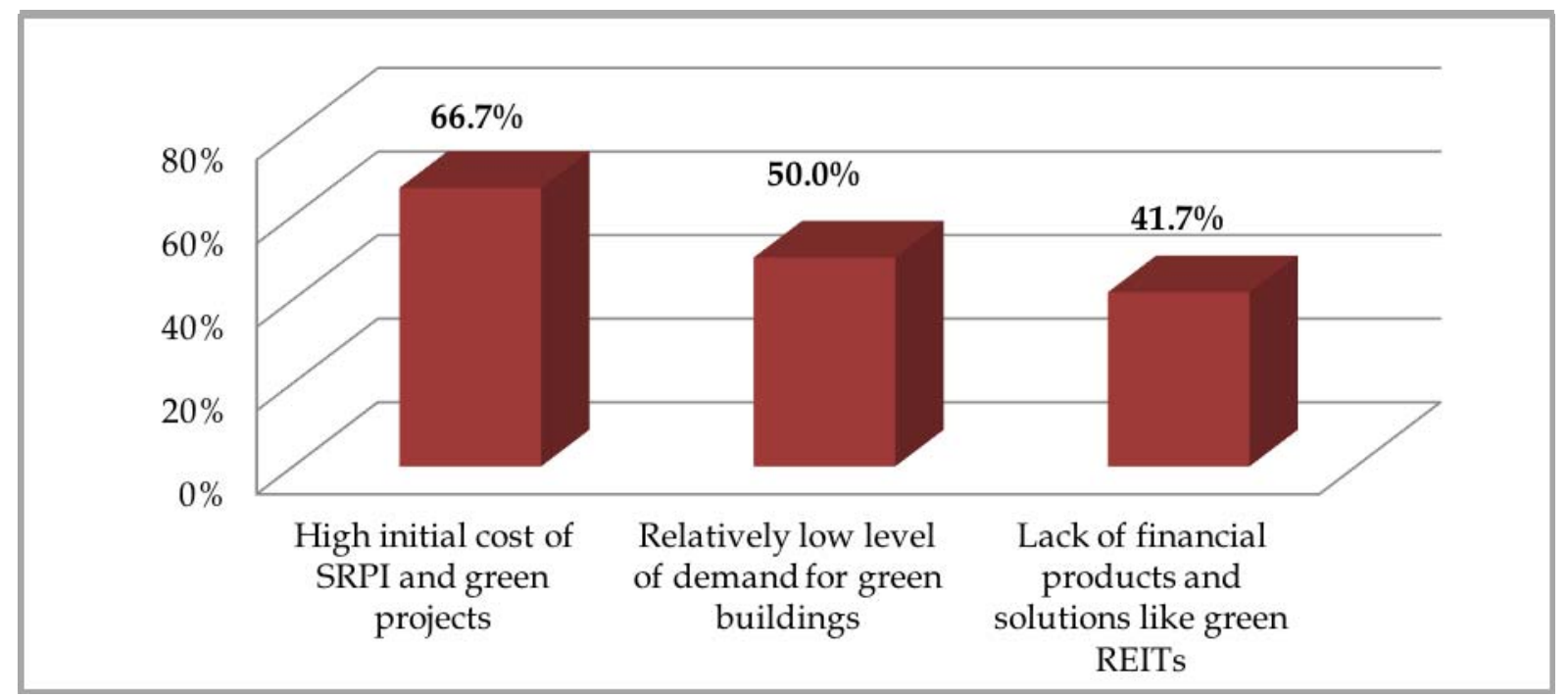

Fig. 1. Economic factors inhibiting the development of SRPI in Poland. Source: own study.

Respondents were also asked to indicate which factors support SRPI in Poland. Significantly, all of them considered the higher valuation of green buildings compared with uncertified ones as the most important economic indicator backing the viability of this type of investment. Another issue potentially supporting SRPI was its use as a risk management tool (90\%). One of the respondents added an explanatory note saying that responsibility could be a risk management tool while dealing with accidents at construction sites. It could be used to prove that the investor cooperated only with subcontractors obeying Occupational Safety and Health regulations (OSH). More than half of the respondents $(58.3 \%)$ decided that lower service charges and utility bills in green projects were 
important incentives to support SRPI implementation. It is important to note here that the majority of respondents represented investors who do not manage the buildings but sell the, and that the future maintenance costs, were, therefore, of secondary importance to them. A much less important factor for respondents was the diversification of their investment portfolio into the traditional and the socially responsible (only $8.3 \%$ ). Figure 2 below illustrates the distribution of answers.

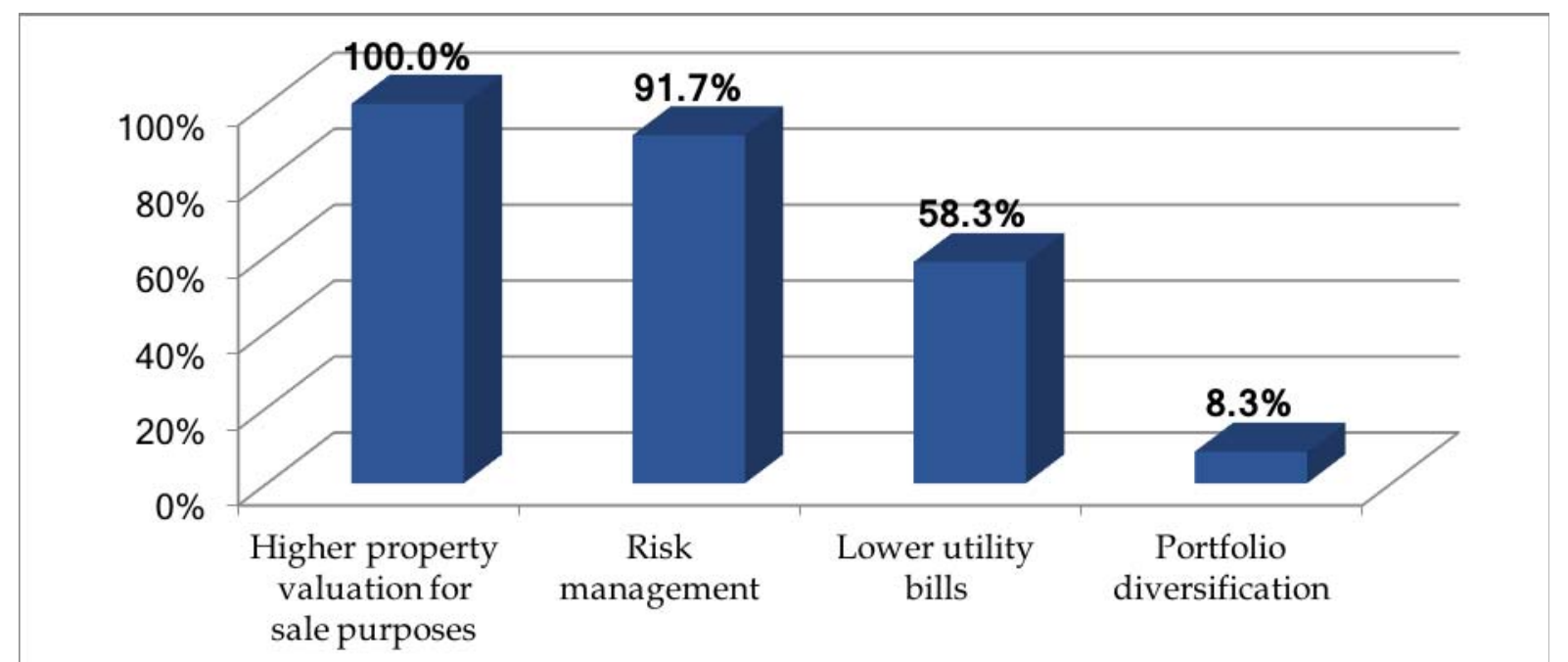

Fig. 2. Economic factors supporting the development of SRPI in Poland. Source: own study.

\subsubsection{Social factors inhibiting and supporting the development of SRPI}

In the social context, most respondents $(83.3 \%)$ chose the lack of management decisions to pursue this type of investment as the most significant barrier to SRPI. Other important issues referred to by experts were the lack of client insistence and interest (58.3\%), and the lack of social pressure on investors to do so $(33.3 \%)$.

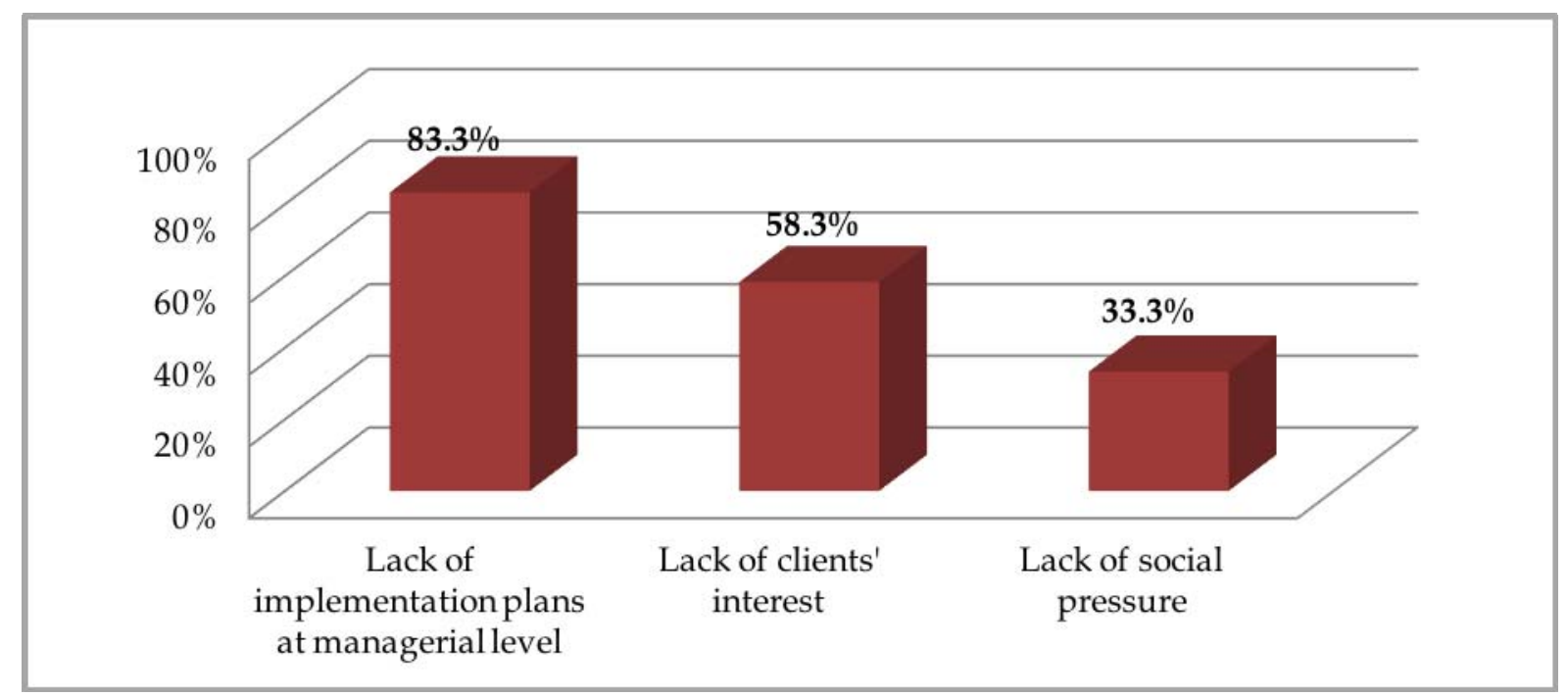

Fig. 3. Social factors inhibiting the development of SRPI in Poland. Source: own study.

Figure 3 below shows the percentage distribution of answers. None of the respondents added comments or mentioned any other issues. This suggests that the most important barriers to SRPI are within companies at the decision-making level, and that the lack of stakeholder pressure only supports this position.

Amongst the social indicators supporting and making responsible investment corporately acceptable, most respondents singled out the opportunity to create a positive image of the company and its PR activities (83.3\%). Significantly fewer experts decided that improvements to the quality of the work environment for future occupiers of properties $(50 \%)$, as well as the urban environment in general $(33.3 \%)$ were important. These answers show that investors operating in the Polish real estate 
market consider SRPI mostly as a PR tool. Issues concerning the impact of their projects on city dwellers and building occupants holds less significance (refer to Figure 4).

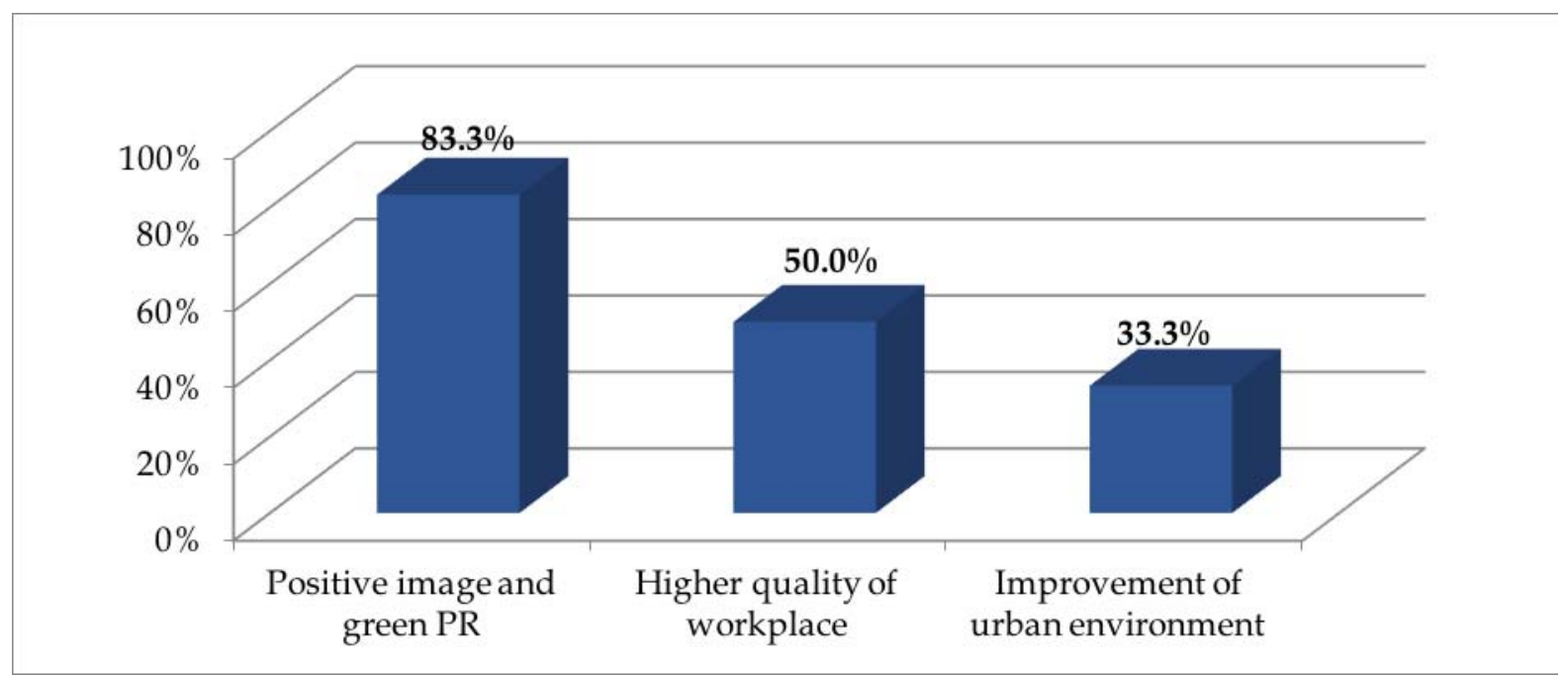

Fig. 4. Social factors supporting the development of SRPI in Poland. Source: own study.

\subsection{SRPI on a micro scale - results from Warsaw case study}

The issue of SRPI was also one of the areas investigated in "Green Strategies for Cities in Poland -a comparative study of Warsaw, Kraków and Poznań". The aim of the study was to investigate green strategies and projects conducted in three Polish cities from 2007 to 2016. It was conducted within the framework of the young scientists research grant from the Collegium of Business Administration, Warsaw School of Economics, between 2015 and 2016. The inquiry was divided into three areas, with SRPI and green buildings being one of them, and public transportation and green and public spaces as two separate areas.

According to a Warsaw city representative, the city is the leading metropolis in Central and Eastern Europe in terms of newly built office space (over 400,000 square meters in recent years) and excels in the number of environmental certificates in the LEED and BREEAM systems that it has been granted. Based on this information and the author's previously discussed study on SRPI, two commercial property companies, Skanska Group and Ghelamco, were investigated further. Both companies create positive PR and publicly share information about their projects and commitment to sustainable development and social responsibility. In the past few years, they have developed over two dozen buildings in the capital, certified in BREAAM or LEED (refer to Table 2 for examples). One of these examples is Towarowa Street in Wola District. Despite its close proximity to the city center (according to Google Maps it is a 5-minute car drive and approximately $1.7 \mathrm{~km}$ distance, see Figure 5), it had been underdeveloped for many years until becoming the current subject of interest of the two corporations. For instance, Skanska is now developing three green offices: Generation Park - Building $X$ and Generation Park - Building Y. The buildings' names refer to the social phenomenon of generations, such as the discussed in section 4.1 Gen Y. They are planned to reflect the various needs of end-users, depending on their requirements and work patterns. The buildings will be one of Warsaw's largest office developments in the recent years, with 84,000 square metres of space. Ghelmaco is the second investor on Towarowa Street. It concluded several project in 2016, including Warsaw Spire A, B and C. The buildings are BREEAM certified and offer not only offices for rent but also a mixed-use and public space called "Plac Europejski" (European Square), with water fountains and urban greenery, designed to encourage use by the local community and make Towarowa Street more liveable. Currently, this street is a transit route for thousands of drivers on the way downtown or back home.

In preparation for further development of commercial space along Towarowa Street and in response to possible doubts of stakeholders, a public consultation initiative entitled "Nowa Towarowa" was launched in late 2015. Doubts regarding future developments are based on the already existing negative example of Domaniewska Street (this is an overdeveloped area with mainly mono-functional office space in Mokotów District). Public bodies and organisations including Wolskie 
Cultural Center and Warsaw branch of the Association of Polish Architects (SARP OW) support this initiative. Skanska and Ghelamco are also involved. The aim of "Nowa Towarowa" is to create both feasible and desirable proposals for further development of the street, incorporating the recognition of its heritage and demands for mixed-use development and open public space. So far, six proposals have been created, including ideas to transform Towarowa Street into a pedestrian area with green public spaces, parks and cycle routes, in contrast to the current traffic jams and lack of any social facilities.

Table 2

Certified buildings of investigated companies in Warsaw

\begin{tabular}{|c|c|c|c|c|c|c|}
\hline $\begin{array}{l}\text { Obtained } \\
\text { certificate }\end{array}$ & $\begin{array}{l}\text { Completed } \\
\text { in }\end{array}$ & $\begin{array}{c}\text { Headquarters } \\
\text { in Poland }\end{array}$ & Company & $\begin{array}{c}\text { New } \\
\text { developments } \\
\text { on Towarowa } \\
\text { Street }\end{array}$ & $\begin{array}{c}\text { Completed } \\
\text { in }\end{array}$ & $\begin{array}{l}\text { Obtained } \\
\text { certificate }\end{array}$ \\
\hline \multirow[t]{2}{*}{$\begin{array}{c}\text { LEED } \\
\text { (Platinum) }\end{array}$} & \multirow[t]{2}{*}{2013} & \multirow[t]{2}{*}{ Atrium 1} & \multirow[t]{2}{*}{$\begin{array}{l}\text { Skanska } \\
\text { Property }\end{array}$} & $\begin{array}{c}\text { Generation } \\
\text { Park - } \\
\text { Building X }\end{array}$ & 2017 & $\begin{array}{c}\text { LEED } \\
\text { (Platinum) }\end{array}$ \\
\hline & & & & $\begin{array}{c}\text { Generation } \\
\text { Park - } \\
\text { Building Y }\end{array}$ & 2019 & $\begin{array}{c}\text { LEED } \\
\text { (Platinum) }\end{array}$ \\
\hline \multirow{3}{*}{$\begin{array}{c}\text { BREEMA } \\
\text { (Very } \\
\text { Good) }\end{array}$} & \multirow[t]{3}{*}{2011} & \multirow{3}{*}{$\begin{array}{c}\text { Mokotów } \\
\text { Nova, } \\
\text { Warsaw }\end{array}$} & \multirow[t]{3}{*}{ Ghelamco } & $\begin{array}{c}\text { Warsaw Spire } \\
\text { B }\end{array}$ & 2014 & $\begin{array}{c}\text { BREEAM } \\
\text { (Excellent) }\end{array}$ \\
\hline & & & & $\begin{array}{c}\text { Warsaw Spire } \\
\text { C }\end{array}$ & 2015 & $\begin{array}{l}\text { BREEAM } \\
\text { (Platinum) }\end{array}$ \\
\hline & & & & $\begin{array}{c}\text { Warsaw Spire } \\
\text { A }\end{array}$ & 2016 & $\begin{array}{c}\text { BREEAM } \\
\text { (Excellent) }\end{array}$ \\
\hline
\end{tabular}

Source: own study based on (www.skanska.pl/pl/Biura/Filtr-powierzchni-do-wynajcia, accessed 12.03.2016), (www.bazabiur.pl/zielone-biura.html, accessed 12.03.2016), (www.ghelamco.com/site/pl/pl/projects/1/R/offices.html, accessed 12.03.2016), (www.ghelamco.com/site/pl/pl/projects/1/U/offices.html, accessed 12.03.2016).

On the one hand, this initiative shows the interest of companies to communicate and consult with stakeholders in the investment process, which is a clear manifestation of social responsibility. On the other hand, the intentions of the companies involved and possible outcomes of "Nowa Towarowa" are not yet clear. There are no specific plans or a time frame to implement any of the proposals. Furthermore, there have been numerous conflicts between these companies - especially Ghelamco and city activist organisations like "Miasto jest Nasze" regarding Towarowa Street. Activists accuse commercial property companies of negligence of built environment heritage in Wola District and the abuse of public space. One of the examples is the recent commercial logo display of a credit card company on the facade of the Warsaw Spire Complex (LED display which is 11 stories high).

\section{Discussion and conclusions}

The results of three studies discussed in this article prove that, at a conceptual level, there is support from commercial investors for SRPI and an understanding of its social and economic principles. However, market practice observed between 2007-2016, firstly on a global scale and then specifically in Poland, demonstrates a different reality. SRPI is manifested primarily in the form of BREEAM and LEED certified buildings, which do not fulfil the principles of SRPI. Energy efficiency and utility bill savings could be easily transformed into economic gains, but social aspects incur extra costs in the investment process, for instance, by dedicating open space to free public use instead of office space 
and car parks.

In Poland, the main challenge for the growth of RPI is the lack of knowledge of potential buyers and tenants about its benefits to them, and the relatively low social pressure exerted on investors. In this context, the key factor in the further development of property developers' social responsibility is the pressure of stakeholders, including local communities affected by investment projects and urban activists, usually acting as whistle blowers. The case of Towarowa Street and the actions taken by the two aforementioned companies prove that there is a fine line between social responsibility and PR actions, and that TBL is still more a concept than a market reality.

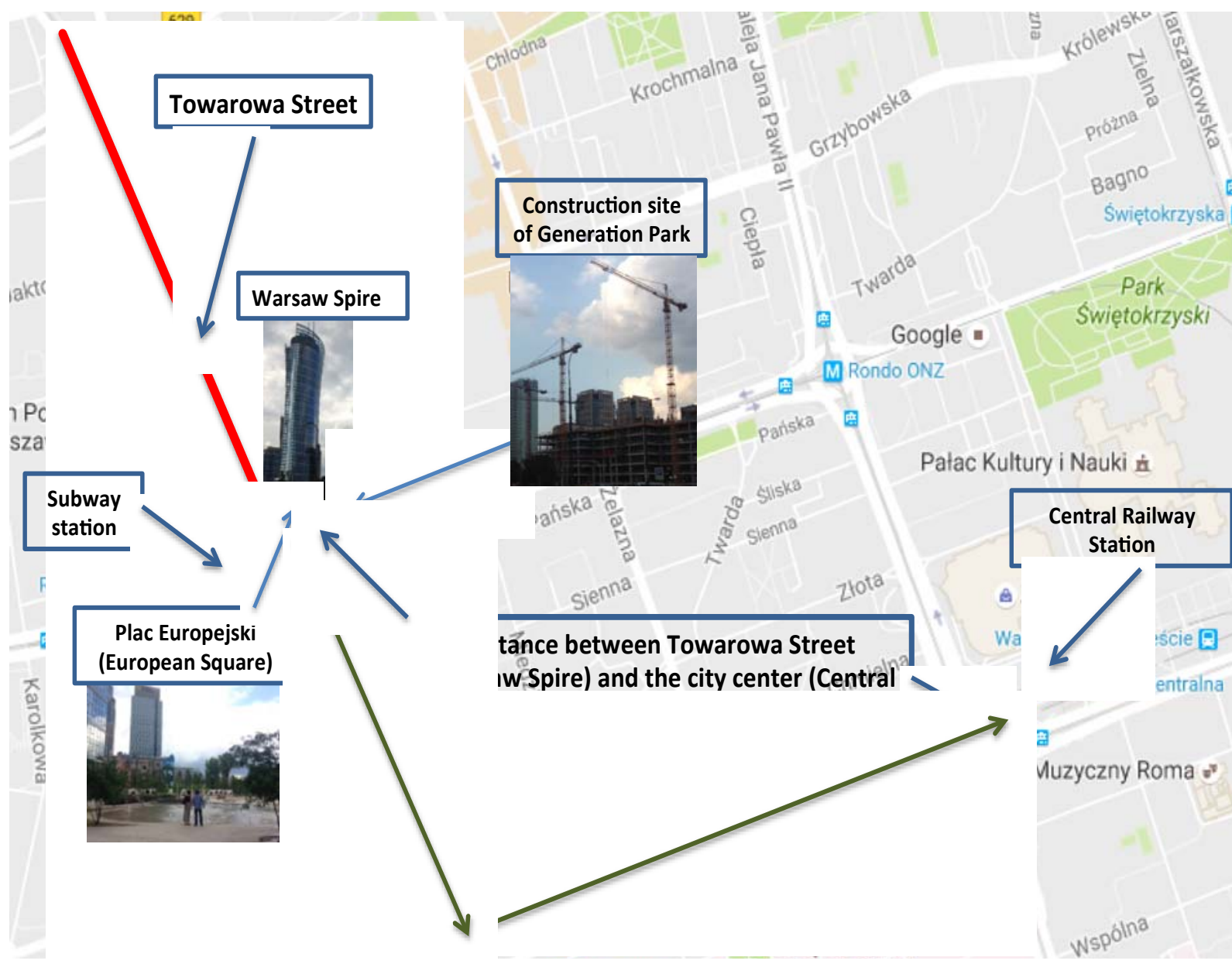

Fig. 5. Towarowa Street and distance to the Central Railway Station in Warsaw. Source: Own elaboration based on Google Maps.

An interesting subject for further studies would be to conduct an interdisciplinary study to empirically test the social benefits of SRPI and their possible influence on property valuation in numerous cities. Specific locations could be chosen on the basis of their level of development, population size and legal regulations encouraging responsible investing. This could include research on the influence of green buildings on the inhabitants of neighbouring communities and users of this space (e.g., workers of nearby companies), as well as the level of liveability in such places. These are challenging issues to investigate, but the result could enable the actual incorporation of social issues into property investing by proving their legal and financial viability to investors.

\section{References}

Adair A., Bery J., Gulati M., Haran M., Hutchison N., Kashyap A., Mccord M., Mcgreal S.,

OVedele J., TiWARI P., 2011, The Future of Private Finance Initiative and Public Private Partnership,

RICS Research, Royal Institution of Chartered Surveyors (RICS), London.

BeLniAK S., GŁUSZAK M., ZIĘBA M., 2013, Budownictwo ekologiczne. Aspekty ekonomiczne (Ecological Property Development. Economic aspects) [in Polish], PWN, Warszawa, p. 415.

BLOOMFIELD J., 2011, Empire State Building Achieves LEED Gold, (www.usgbc.org/articles/empire- 
state-building-achieves-leed-gold, accessed 2.03.2016).

Brodowicz D., PosPiesZnY P., GrZYMala Z., 2015, Eco-cities, CeDeWu, Warszawa, pp. 47-54.

BRYX M., Ed., 2014, Innowacje w konsultacjach spotecznych (Innovations in Public Consultations) [in Polish], [In:] Innowacje w zarządzaniu miastami w Polsce (Innovations in City Management in Poland), Oficyna Wydawnicza SGH w Warszawie, Warszawa, pp. 236-238.

COLLIERS, 2012, Poland, Green Building Review, (www.colliers.com/ /media/files/emea/poland/ reports/2012/q1-2012-pl-green-building-review-en.pdf, access 2.03.2016).

EeriKAINEN H., SARAsOJA A. L., 2013, Marketing Green Buildings - Well-Structured Process or Forgotten Minor Detail? Evidence from Finland, Property Management, 31 (3), pp. 233-236.

DENZIN N.K., LINCOLN Y.S. (ed.) 2005, Handbook of qualitative research, SAGE Publications.

ELKINGTON J., 2004, Enter the Triple Bottom Line. The Triple Bottom Line: Does it all Add Up?, pp. 1-16 (www.johnelkington.com/archive/TBL-elkington-chapter.pdf, access 2.03.2016).

ELLISON L., SAYCE S., 2007, Assessing Sustainability in the Existing Commercial Property Stock, Property Management, 25 (3), p. 302.s[E:

HiRSCH J., BRAUn T, BIENERT S., 2015, Assessment of Climatic Risks for Real Estate, Property Management, $33(5)$, p. 512.

JunNILA S., 2004, The Environmental Significance of Facilities in Service Sector Companies, Facilities, 22 (7/8), pp. 190-198.

KuCHARSKA-STASIAK E., ZRÓBEK S., 2015, An Attempt to Exemplify the Economic Principles in Real Property Valuation, Real Estate Management and Valuation, 23 (3), pp. 5-13.

MARCINEK K, 2012, Społecznie odpowiedzialne inwestowanien na rynku nieruchomości (Socially Rresponsible Property Investing in the Real Estate Market) [in Polish] [In:] Inwestycje i nieruchomości - wybrane zagadnenia (Investment and Properties - Selected Issues), Ed. MARCINEK K., Studia Ekonomiczne, Zeszyty Naukowe Wydziałowe Uniwersytetu Ekonomicznego w Katowicach, Katowice, 2012, p. 173.

MORTON L. P., 2002, Targeting Generation Y. Public Relations Quarterly, 47 (2), p. 46.

NEUHAUSER K.L., 2015, The Global Financial Crisis: What have we Learned So Far?, International Journal of Managerial Finance, 11 (2), pp. $134-161$.

PIVo G., 2005, Is there a Future for Socially Responsible Property Investments?. Real Estate Issues, 30 (1), pp. 16-27.

Pivo G., MCNAmara P., 2005, Responsible Property Investing, International Real Estate Review, 8 (1), p. 129.

RATClifFe J., O'BRIEN G., BRODOWICZ D.P., 2009, Built Environment Foresight 2030: Sustainable Development Imperative, The Futures Academy, DIT, Dublin, pp. 27-64.

SOCIAL InVESTMENT FORUM (SIF), 2003, Report on Socially Responsible Investing Trends in the United States. Washington, D.C.: Social Investment Forum.

SAyCE S., 2013, Sustainability and Real Estate Values: Time for the Agenda to Move on?, Property Management, 31 (3).

SCHUETH S., 2003, Socially Responsible Investing in the United States, Journal of Business Ethics, 43(3), pp. 189-194.

SHIERS D.E., 2000, "Green" Developments: Environmentally Responsible Buildings in the UK Commercial Property Sector, Property Management, 18 (5), p. 352.

SIEMIŃSKA E., 2013, Ryzyka inwestowania i finansowania na rynku nieruchomości w kontekście etyki $i$ spotecznej odpowiedzialności (Investment and Financial Risk on the Real Estate Market in the Context of Ethics and Social Responsibility) [in Polish], Wydawnictwo Naukowe UMP w Toruniu, Torun, pp. 236-263.

SLAPER T. F., HALl T. J., 2011, The Triple Bottom Line: What Is It and How Does It Work?, Indiana Business Review (http://www.ibrc.indiana.edu/ibr/2011/spring/article2.html, accessed 6.03.2016).

Squires G., HUtChison N., ADAIR A., BerRy J., MCGREAL S., OrGAN S., 2016, Innovative Real Estate Development Finance - Evidence from Europe, Journal of Financial Management of Property and Construction, 21 (1), p.55.

NeWEll G., 2009, Developing a Socially Responsible Property Investment Index for UK Property Companies, Journal of Property Investment \& Finance, 27 (5), pp. 511-521.

UNEP FI, 2016, Real Estate Investment Implementing the Paris Climate Agreement: an Action Framework (www.unepfi.org/fileadmin/documents/SustainableRealEstateInvestment.pdf, accessed 
2.03.2016).

US SIF, 2014, Annual Report, (www.ussif.org/files/Publications/Annual_\%20Report_14_FINAL.PDF, accessed 5.03.2016).

YUDELSON J., 2008, The Green Building Revolution, Island Press, Washington.

WANG A.F., ZHANG T., 2013, Financial Crisis and Credit Crunch in the Housing Market, The Journal of Real Estate Finance and Economics 2 (49), pp. 256-276.

World Commission on Environment and Development, 1987, Our Common Future, Oxford Uniaversity Press, Oxford.

www.bazabiur.pl/zielone-biura.html, accessed 12.03.2016.

www.ghelamco.com/site/pl/pl/projects/1/R/offices.html, accessed 12.03.2016.

www.ghelamco.com/site/pl/pl/projects/1/U/offices.html, accessed 12.03.2016.

www.skanska.pl/pl/Biura/Filtr-powierzchni-do-wynajcia, accessed 12.03.2016. 